\title{
FAKTOR -FAKTOR YANG MEMPENGARUHI TERJADINYA SALAH PERLAKUAN TERHADAP LANSIA
}

\author{
Yori Yolanda, Efri Widianti* \\ Fakultas Keperawatan, Universitas Padjadjaran, Jl. Raya Bandung-Sumedang KM. 21, Hegarmanah, Jatinangor, \\ Hegarmanah, Kec. Jatinangor, Kabupaten Sumedang, Jawa Barat, Indonesia 45363 \\ *efri358@gmail.com
}

\begin{abstract}
ABSTRAK
Salah perlakuan adalah suatutindakan disengaja yang menimbulkan bahaya atau suatu kegagalan caregiver dalam memenuhi kebutuhan dasar lansia. Pelaku salah perlakuan lansia yang ditemui di rumah biasanya dilakukan oleh anak laki-laki ataupun keluarga yang merawat lansia. Dampak negatif akibat dari salah perlakuan yaitu cemas dan depresi serta kematian setelah 7 sampai 8 tahun kemudian.Tujuan dari tinjauan ini adalah untuk mengetahui faktor resiko yang mempengaruhi terjadinya salah perlakuan terhadap lansia.Pencarian literatur menggunakan elektronik database melalui Google Scholar, Proquest dan PubMed, menggunakan kata kunci faktor resiko, lansia dan salah perlakuan. Kriteria inklusi adalah:artikel fulltext yang diterbitkan antara 2008-2018, bahasa inggris dan bahasa indonesia, pencarian artikel yang relevan dengan tema yang akan diambil. Berdasarkan searching menggunakan kata kunci diperoleh 1100 artikel. Didapatkan 11 artikel yang memenuhi kriteria inklusi.Faktor resiko yang mempengaruhi terjadinya salah perlakuan terhadap lansia antara lain rendahnya dukungan sosial, beban stres dari caregiver, kerusakan kognitif lansia, tingkat ekonomi rendah dan ketergantungan fungsi fisik seperti lansia memerlukan bantuan dalam kegiatan sehari-hari. Mengetahui faktor resiko sangat penting guna mencegah tindakan salah perlakuan pada lansia dan meningkatkan kualitas hidup lansia.
\end{abstract}

Kata kunci: faktor resiko, lansia, salah perlakuan

\section{FACTORS THAT AFFECT ELDERLY ABUSE}

\begin{abstract}
Elder abuse isan intentional act, which causes harms or failures by a caregiver to satisfy the elder's basic needs. Perpetrators of abuse are typically described as male or family members who are looking for elderly person. The negative effects of elderly abuse are anxiety and depressionas well as death after 7 to 8 years later. The objective of this study was to identify the risk factors contributing to elder abuse.Literature research in this study was conducted through three electronic databases namely Google Scholar, Proquest and PubMed, using the keywords elderly, abuse and risk factor.Inclusion criteria are: full-text articles published in English language between 2008-2018, and the search of articles which are relevant to the theme. Based on the literature search by using keywords that mentioned before, it was obtained 1100 articles. Among those articles, there were 11 articles that met the inclusion criteria. The risk factorscontributing to elder abuseare low of social supports, caregiver burden and stress, cognitive disorders, poor economic conditions, and functional dependence in the elderly like becoming dependent on others for help in performing daily living activities. Knowing the risk factors is very helpful in preventing abuse of the elderly and improving the quality of life for the elderly.
\end{abstract}

Keywords: abuse, elderly abuse, risk factor

\section{PENDAHULUAN}

Lansia $\geq 60$ tahun rentan terhadap penyakit dan rentan mengalamiberbagai bentuk kejahatan lainnya, salah satunya adalah salah perlakuan (Rismanda, 2015; Julianti, 2017).Elderly abuseatauelder mistreatment adalah suatutindakan disengaja yang menimbulkan bahaya atau suatu kegagalan caregiver dalam memenuhi kebutuhan dasar lansia (Pillemer et al, 2015). Salah perlakuan pada lansia merupakan suatu tindakan membahayakan pada lansia yang rentan dilakukan oleh seseorang yang mempunyai hubungan yang dekat dengan lansia (Wangmo, Nordstrom \& Kressig, 2017). Tindakan ini menjadi salah satu pelanggaran hak asasi manusia yang membutuhkan deteksi dinidengan segera dikarenakan mengakibatkan 
masalah kesehatan yang akan meningkatkan resiko kematian, kesakitan, masuk rumah sakit, serta memiliki dampak negatif bagi keluarga dan masyarakat (Yon, Mikton, Gassoumis \& Wilber, 2017)

Dampak negatif yang muncul dari salah perlakuan pada lansia adalah luka fisik, cemas, dan pengabaian terhadap diri sendiri (Mosqueda \& Dong, 2011). Rovi (2010) juga menjelaskan salah perlakuan terhadap lansia akan meningkatkan resiko kematian setelah terjadinya penyakit kronis yang mereka miliki, cidera traumatis serta efek psikologis seperti depresi dan cemas. Selain itu akan adanya dampak fisik yang muncul seperti luka, gangguan gastrointestinal, kelelahan, tekanan darah tinggi, masalah jantung dan nyeri kronis. The Chicago Health Aging Project juga melaporkan tindakan salah perlakuan akan menyebabkan gangguan mental dan kematian setalah 7 sampai 8 tahun kemudian. Dampak ini terjadi dikarenakan beberapa tindakan salah perlakuan lansia seperti salah perlakuan fisik, salah perlakuan finansial, salah perlakuan psikologis, salah perlakuan seksual, dan pengabaian (Joshi \& Flaherty, 2005).

Hasil penelitian Skirbekk\& James (2014) di India ditemukan sebesar $11 \%$ lansia mengalami salah satu dari salah perlakuan (fisik 5,3\%, verbal 10,2\%, ekonomi 5,4\%, pengabaian 5,2\%). Sedangkan terdapat presentasi yang besar di negara Nepal, ditemukan bahwa $47 \%$ lansia mengalami pengabaian, $37 \%$ salah perlakuan emosional, $32 \%$ salah perlakuan ekonomi, $8 \%$ salah perlakuan fisik dan 3\% salah perlakuan seksual (Rai, Khanal \& Chalise, 2018). Khususnya di Indonesia belum terdapat data nasional yang menggambarkan presentasi atau besarnya salah perlakuan pada lansia. Tindakan salah perlakuan dan pengabaian mayoritas tidak dilaporkan karena terjadi pada lansia yang berada dirumah (Carmen \& LoFoso, 2014). Hasil penelitian dari Lacher et al (2016) juga mendukung bahwa salah perlakua pada lansia sering terjadi dirumah daripada di panti jompo. Untuk itu mengetahui adanya tindakan salah perlakuan pada lansia di Indonesia sangat penting dikarenakan dapat mencegah terjadinya salah perlakuan lansia guna meminimalisir dampak dan dapat melakukan tindak lanjut atau intervensi secara dini. Oleh karena itu, perlu adanya penyusunan systematic review guna mengetahui faktor- faktor yang mempengaruhi tindakan salah perlakuan pada lansia.

\section{METODE}

Proses penyusunan sistematik review yang telah dilakukan dengan cara melakukan pencarian artikel menggunakan database elektronik yaitu Google Schoolar, PubMed dan Proquest. Kata kunci dalam bahasa indonesia dan bahasa inggris antara lain :"faktor resiko", "salah perlakuan", "lansia", "elderly abuse", "elder misstreatment", "risk factors" dan "family caregiver". Hasil pencarian artikel yang ditemukan di google schoolar sebanyak 279 artikel, pubMed sebanyak 511 artikel dan proquest sebanyak 210 artikel. Kriteria inklusi dalam pencarian artikel antaralainartikel fulltext yang diterbitkan antara 2008-2018, bahasa inggris dan indonesia dan artikel yang relevan dengan tema yang akan diambil. Setelah dilakukan kritisi artikel menurut kriteria inklusi tersebut, maka ditemukan artikel sebanyak 11 artikel yang terdiri dari database Google Schoolar 5 artikel, PubMed 5 artikel dan proquest 1 artikel.

\section{HASIL}

Hasil literature review mengidentifikasi faktor-faktor yang mempengaruhi terjadinya salah perlakuan pada lansia.Adapun faktorfaktornya antaralain rendahnya dukungan sosial, beban stres dari caregiver, kerusakan kognitif lansia, tingkat ekonomi rendah dan ketergantungan fungsi tubuh/disability.

1. Rendahnya Dukungan Sosial

Menurut penelitian Wang, Brisbin, Loo dan Starus (2015) menjelaskan 5777 lansia di Amerika Serikat mengalami salah perlakuan. Salah satu yang menyebabkan hal tersebut adalah rendahnya dukungan sosial. Sama halnya dengan hasil survey pada lansia di negara spanyol mengalami salah perlakuan psikologis dikarenakan kurangnya dukungan sosial seperti dukungan dari tetangga atau masyarakat sekitar. Hal tersebut juga didukung oleh penelitian dari Dong (2015), lansia yang berumur 60 tahun keatas sebanyak $30 \%$ beresiko tinggi mengalami salah perlakuan atau pengabaian yang berupa gejala distres psikologis karena tidak adanya dukungan sosial.

\section{Beban stres dari caregiver}

Faktor resiko yang mempengaruhi terjadi dalam meningkatnya tindakan salah perlakuan pada lansia yaitu peranan dari caregiver. 
Menurut penelitian yang dilakukan oleh Skirbeek \& James (2014) menemukan Sebesar $11 \%$ lansia mengalami salah satu salah perlakuan (fisik $5,3 \%$, verbal $10,2 \%$, ekonomi $5,4 \%$, pengabaian $5,2 \%$ ) dan pelaku dari salah perlakuan lansia yang ditemui dirumah biasanya dilakukan oleh anak laki-laki dari lansia tersebut. Didukung oleh penelitian Lachs \& Pillemer (2015), korban salah perlakuan banyak ditemukan pada lansia perempuan yang tinggal bersama dengan anaknya yang sudah berkeluarga dan memiliki anak laki-laki yang sudah dewasa, dimana 2 orang kelompok yang tinggal bersama lansia tersebut berpotensi menjadi pelaku pelecehan. Caregiver mengakui bahwa merawat lansia membutuhkan tenaga dan waktu yang lebih serta emosi yang stabil.Penelitian kualitatif yang dilakukan oleh Nugraha (2018) menjelaskan fenomena terjadinya pelecehan disebabkan oleh caregiver yang mengalami kelelahan dalam merawat lansia.

\section{Kerusakan kognitif lansia}

Menurut penelitian yang dilakukan oleh Mosqueda \& Dong (2011), salah satu faktor yang menyebabkan salah perlakuan pada lansia yaitu kerusakan kognitif. Terdapat pengaruh yang signifikan antara kerusakan kognitif dan tindakan salah perlakuan. Penelitian ini menjelaskan ketika seorang lansia mengalami kerusakan kognitif maka konsentrasi, daya ingat dan daya berfikir lansia akan mengalami penurunan. Lansia menganggap bahwa keluarga tidak merawatnya dengan baik. Fisher dan Regan (2008) dengan judul penelitian "The extent and frequency of abuse in the lives of older women and their relationship with health outcomes" mejelaskan bahwa kerusakan kognitif pada lansia perempuan akan menyebabkan tingkat tindakan salah perlakuan semakin meningkat. Orang lain ataupun keluarga menganggap bahwa lansia tidak berdaya dan tidak perlu untuk dirawat. Hal yang sama juga dikatakan oleh Phiharmanto (2017), terdapat hubungan tingkat stress keluarga dengan kualitas perawatan lansia dengan gangguan kognitif yang dialami lansia.

\section{Tingkat ekonomi yang rendah}

Ekonomi yang rendah menjadi salah satu faktor resiko akan terjadinya salah perlakuan pada lansia (Lacher et al, 2016). Burnes et al (2015) dalam penelitiannya yang bertujuan untuk mengidentifikasi resiko terjadinya salah perlakuan emosional, salah perlakuan fisik dan pengabaian pada lansia menemukan bahwa salah perlakuan emosional dan fisik dikaitkan dengan adanya perceraian dan ekonomi rendah. Neglect dikaitkan dengan kesehatan yang buruk, perceraian serta ekonomi rendah. Dapat disimpulkan bahwa faktor ekonomi akan mempengaruhi adanya tindakan salah perlakuan.

\section{Ketergantungan fungsi tubuh lansia}

Penelitian tentang salah perlakuan terhadap lansia di korea yang dilakukan oleh Oh et al (2006), ditemukan rata-rata lansia mengalami salah perlakuan emosional yang dilakukan dirumah yakni sebesar 6,3\%. Faktor resiko terjadinya pelecehan tersebut dinilai dari 2 sudut pandang yaitu karakterisitik personal dan karakteristik keluarga. Karakteristik personal (lansia) seperti umur ketergantungan fungsi fisik sedangkan karakteristik keluarga seperti keadaan rumah tangga (perceraian), tingkat ekonomi keluarga dan kualitas hubungan keluarga. Hal tersebut didukung oleh Lach dan Pillemer (2015), rendahnya kesehatan fisik seperti lansia membutuhkan pertolongan orang lain dalam melakukan kegitaan sehari-hari akan menyebabkan terjadinya salah perlakuan pada lansia.

\section{PEMBAHASAN}

1. Rendahnya dukungan sosial

Lansia merupakan fase akhir dalam kehidupan yang akan mengalami penurunan kondisi fisik, psikologis, maupun sosial. Support sosial sangat berpengaruh terhadap kondisi psikologis lansia. Hal ini dikemukan menurut Ulfa, Gestia dan Restu (2018) yang mengungkapkan ketika lansia merasakan bahwa dirinya mendapat dukungan sosial maka lansia akan merasakan kehidupan di akhir tua nya bahagia dan sehat. Dukungan dibagi menjadi 2 yakni dukungan keluarga dan dukungan sosial. Friedman (2010), dukungan keluarga juga menjadi penting karena keluarga berfungsi sebagai sistem pendukung bagi anggota keluarganya dan siap untuk memberikan pertolongan dalam bentuk apapun. 7 jenis dukungan keluarga terhadap lansia yakni dukungan keluarga melalu komunikasi, dukungan emosional, dukungan melalui interaksi sosial, dukungan keluarga melalui finansial, dukungan keluarga dalam pelayanan transportasi, dukungan melalui upaya dalam mempertahankan aktivitas yang masih dilakukan lansia, dan dukungan keluarga dalam menyiapkan makanan. Dapat disimpulkan bahwa untuk mencegah terjadinya 
salah perlakuan ataupun pengabaian, lansia membutuhkan dukungan keluarga dan dukungan sosial yang tinggi.

\section{Beban stres dari caregiver}

Caregivermerupakan orang yang merawat dan memberikan kenyamanan dengan tujuan agar kebutuhan sehari-hari lansia dapat terpenuhi (Timby, 2009).Chorwe-sungani et al (2015) menjelaskan caregiver berpartisipasi dalam perawatan, berinteraksi dan menghormati pasien, serta berbagi informasi dan mencari informasi tentang penyakit yang diderita pasien. Caregiver bisa berasal dari anggota keluarga, teman bahkan tenaga professional/perawat yang mendapat uang sebagai imbalan karena sudah merawat lansia (Nadiya, 2009).

Teori mengenai salah perlakuan diusulkan pertama kali oleh Karl Pillemer, seorang sosiologis dan Suzane Steinmets, seorang psikologis dan ahli dalam kekerasan pada tahun 1981. Para ahli tersebut menemukan bahwa resiko terjadinya salah perlakuan yaitu pada usia 60 tahun keatas dan dilakukan oleh anggota keluarga yang tinggal bersama dengan lansia yaitu keluarga yang merawat lansia (family caregiver). Tipe familycaregiver yang melakukan salah perlakuan pada lansia yang dijelaskan oleh Murray dan Zetner (2001) adalah caregiver dengan stress ekonomi, penyalahgunaan zat, memiliki riwayat sebagai korban kekerasan di keluarga, kelelahan dan furstasi dalam merawat lansia. Didukung hasil penelitian yang dilakukan oleh Eska dkk (2015) yang berjudul "Prediktor pola caregiving keluarga terhadap lanjut usia" menjelaskan terdapat beban keluarga dalam merawat lansia yang ditunjukan dengan ungkapan rasa lelah, jenuh dan capek serta kesulitan keluarga membagi waktu antara merawat lansia dan peran dari caregiver.

Yuliati \& Ririanty (2014) menjelaskan keluarga diharapkan dapat menjaga komunikasi dengan lansia dalam perawatannya dengan lebih banyak mendengarkan keluhan dari lansia dan memberikan solusi yang dibutuhkan oleh lansia baik dari masalah kesehatan maupun hubungan sosialnya (Yunita, 2013). Maka dapat disimpulkan bahwa caregiver harus bisa memahami lansia.

\section{Kerusakan kognitif}

Individu yang berusia 45 tahun keatas akan mengalami penurunan kognitif, akan tetapi terjadi penurunan kognitif yang sangat cepat ketika individu berusia 60 tahun ketas atau yang sering kita katakan yaitu lansia. Lansia yang mengalami penurunan daya ingat/kehilangan memori akan memperlihatkan tingkah laku yang sulit untuk dimengerti meliputi menurunnya daya ingat untuk peristiwa yang baru terjadi, peningkatan kewaspadaan, perubahan pola tidur dengan suatu kecenderungan untuk tiduran di waktu siang (Maryam, 2008). Dengan perubahan yang terjadi pada lansia, seseorang yang merawat lansia harus peka dan paham akan hal itu. Ketika perubahan tersebut tidak dipahami, maka akan terjadi suatu pelecehan ataupun pengabaian.

Fungsi kognitif ini juga erat hubungannya dengan kualitas hidup lansia. Kualitas hidup dan peningkatan dalam kesejahteraan fisik lansia seperti lansia yang bebas dari penyakit dan fungsi kognitif yang baik merupakan indikator bahwa lansia tersebut dapat mencapai penuaan yang sukses (successful aging) (Deep \& Jeste, 2006)

\section{Tingkat ekonomi yang rendah}

Salah perlakuan pada lansia merupakan kegagalan caregiver dalam memenuhi kebutuhan dasar lansia. Kebutuhan dasar antara lain pemenuhan kebutuan nutrisi, spiritual, Salah satu salah perlakuan yaitu Salah perlakuan finansial yang ditandai dengan adanya penyalahgunaan pendapatan lansia oleh caregiver, memaksa lansia menandatangani urusan keuangan tanpa sepengetahuan lansia tersebut atau lansia menyatakan bahwa dirinya kekurangan uang dalam pemenuhan kebutuhan sehari-hari (Madina dan Dwimartutie, 2017). Hal tersebut membuktikan bahwa tingkat ekonomi yang rendah akan mempengaruhi adanya salah perlakuan yaitu salah perlakuan finansial.

\section{Ketergantungan fungsi tubuh}

Mayoritas lansia memiliki ketergantungan fungsi tubuh atau fisik yang menyebabkan lansia membutuhkan pertolongan orang lain. Lansia yang menderita suatu penyakit bisa berupa penyakit fisik maupun mental, salah satunya adalah demensia. Lansia dengan demensia tidak lagi mampu untuk menopang hidupnya sendiri, melepas pakaian atau memakai pakaian saja juga seringkali mereka membutuhkan bantuan orang lain. Seringkali lansia dengan demensia ini juga mengalami perubahan perilaku, perubahan emosi sehingga 
semakin menyulitkan mereka yang memiliki tanggung jawab untuk merawat. Tanggung jawab untuk merawat ini umumnya yaitu anak, suami/isteri, atau menantu. Sehingga dengan karakteristik tersebut, lansia dengan demensia menjadi beberapa kali lipat lebih rentan mengalami salah perlakuan atau kekerasan (Yuliawati \& Handadari, 2013).

\section{SIMPULAN}

Faktor-faktor yang mempengaruhi terjadimya salah perlakuan antaralain rendahnya dukungan sosial, beban stres dari caregiver, kerusakan kognitif lansia, tingkat ekonomi rendah dan ketergantungan fungsi tubuh/disability.Mengetahui faktor resiko sangat penting guna mencegah tindakan salah perlakuan pada lansia dan hal tersebut akan meningkatkan kualitas hidup lansia

\section{DAFTAR PUSTAKA}

Burnes, D., Pillemer, K., Caccamise, P. L., Mason, A., Henderson, C. R., Berman, J., ... \& Salamone, A. (2015). Prevalence of and risk factors for elder abuse and neglect in the community: a population-based study. Journal of the American Geriatrics Society, 63(9), 1906-1912.

Chorwe-Sungani, G., Namelo, M., Chiona, V., \& Nyirongo, D. (2015). The views of family members about nursing care of psychiatric patients admitted at a mental hospital in Malawi. Open Journal of Nursing, 5(03), 181.

Del Carmen, T., \& LoFaso, V. M. (2014). Elder neglect. Clinics in geriatric medicine, 30(4), 769-777

Depp C. A., Jeste D. V. (2006). Definitions and predictors of successful aging: a comprehensive review of larger quantitative studies. American Journal of Geriatric Psychiatry, 14, 6-20 doi:10.1097/01.JGP.0000192501.03069. bc.

Dong, X. (2015). Screening for elder abuse in healthcare settings: why should we care, and is it a missed quality indicator? Journal of the American Geriatrics Society, 63(8), 1686-1692.

Eska, N. M. R. W. P., Kariman, R., \& Sofyan, N. S. (2015). Prediktor Pola Caregiving Keluarga terhadap Lanjut Usia. Jurnal Keperawatan, 1(1), 57-66.
Joshi, S., \& Flaherty, J. H. (2005). Elder abuse and neglect in long-term care. Clinics in geriatric medicine, 21(2), 333-354

Lacher, S., Wettstein, A., Senn, O., Rosemann, T., \& Hasler, S. (2016). Types of abuse and risk factors associated with elder abuse. Swiss Med Wkly, 146, w14273

Lachs, M. S., \& Pillemer, K. A. (2015). Elder abuse. New England Journal of Medicine, 373(20), 1947-1956.

Madina, U. U., \& Dwimartutie, N. (2017). Salah Perlakuan terhadap Orang Tua: Faktor Risiko dan Tatalaksana. Jurnal Penyakit Dalam Indonesia, 3(1), 52-58.

Mosqueda L, Dong X: Elder abuse and selfneglect: "I don't care anything about going to the doctor, to be honest...". JAMA 2011, 306:532-540.

Mouton CP, Rodabough RJ, Rovi SL, Brzyski RG, Katerndahl DA. Psychosocial effects of physical and verbal abuse in postmenopausal women. Ann Fam Med 2010;8:206-213

Nugraha, R. Y. (2018). Representasi Kekerasan Terhadap Lansia Dalam Rumah Tangga Pada Drama Ninkyo Herupaa (Doctoral dissertation, Universitas Airlangga).

Priharmanto, A. (2017). Hubungan Tingkat Stres Keluarga Dengan Kualitas Perawatan Lansia Dengan Gangguan Kognitif Di Dusun Ngabean Triharjo Pandak Bantul Yogyakarta (Doctoral dissertation, STIKES Jenderal Achmad Yani Yogyakarta).

Rai, S., Khanal, P., \& Chalise, H. N. (2018). Elderly abuse experienced by older adults prior to living in old age home in kathmandu. J Gerontol Geriatr Res, $7(1)$.

Skirbekk, V., \& James, K. S. (2014). Abuse against elderly in India-The role of education. BMC public health, 14(1), 336.

Timby, B. K. (2009). Fundamental Nursing Skills and Concepts. Philadelphia: Lippincot William \& Wilkins

Ulfa, G., Restu, Y. S., \& Psi, M. (2018). Hubungan Antara Stres, Harga Diri Dan Dukungan Sosial Terhadap Kesejahteraan Psikologis Pada Lanjut Usia (Doctoral dissertation, Universitas Muhammadiyah Surakarta). 
Wangmo, T., Nordström, K., \& Kressig, R. W. (2017). Preventing elder abuse and neglect in geriatric institutions: Solutions from nursing care providers. Geriatric Nursing, 38(5), 385-39

Yon, Y., Mikton, C. R., Gassoumis, Z. D., \& Wilber, K. H. (2017). Elder abuse prevalence in community settings: a systematic review and meta-analysis. The Lancet Global Health, 5(2), e147e156.

Yuliati, A., \& Ririanty, M. (2014). Perbedaan Kualitas Hidup Lansia yang Tinggal di Komunitas dengan di Pelayanan Sosial Lanjut Usia (The Different of Quality of Life Among the Elderly who Living at
Community and Social Services). Pustaka Kesehatan, 2(1), 87-94.

Yuliawati, A. D., \& Handadari, W. (2013). Hubungan antara Tingkat Stres dengan Tindak Kekerasan pada Caregiver Lansia dengan Demensia. Jurnal Psikologi Klinis dan Kesehatan Mental, 2(1), 49.

Yunita, M. (2013). Hubungan Dukungan Keluarga dengan Kualitas Hidup Lansia di RW 002 Kelurahan Duri Kepa Jakarta Barat Tahun 2013. Hubungan Dukungan Keluarga Dengan Kualitas Hidup Lansia Di Rw 002 Kelurahan Duri Kepa Jakarta Barat Tahun 2013 